\title{
Characterization of cassava production in the Igarapé-Açu community, Capitão Poço, Pará, Brazil
}

\author{
Samara Ketely Almeida de Sousa ${ }^{1 *}$, Helen Patrícia Moreira Negrão ${ }^{1}$, Letícia do Socorro Cunha ${ }^{2}$, Thiago \\ Feliph Silva Fernandes ${ }^{3}$, Júlia Karoline Rodrigues das Mercês ${ }^{3}$, Wanderson Cunha Pereira ${ }^{4}$, Edmilson \\ Barbosa do Nascimento ${ }^{1}$, Marlon Sheldon da Silva Galdino ${ }^{1}$ and Amanda Catarine Ribeiro da Silva ${ }^{1}$ \\ ${ }^{1}$ Federal Rural University of the Amazon, Capitão Poço, PA, Brazil. \\ ${ }^{2}$ State University of Western Paraná, Marechal Cândido Rondon, PR, Brazil. \\ ${ }^{3}$ Paulista State University Júlio Mesquita de Filho, Jaboticabal, SP, Brazil. \\ ${ }^{4}$ Federal University of Pará, Bragança, PA, Brazil. \\ *Author for correspondence: samarasousa664@gmail.com
}

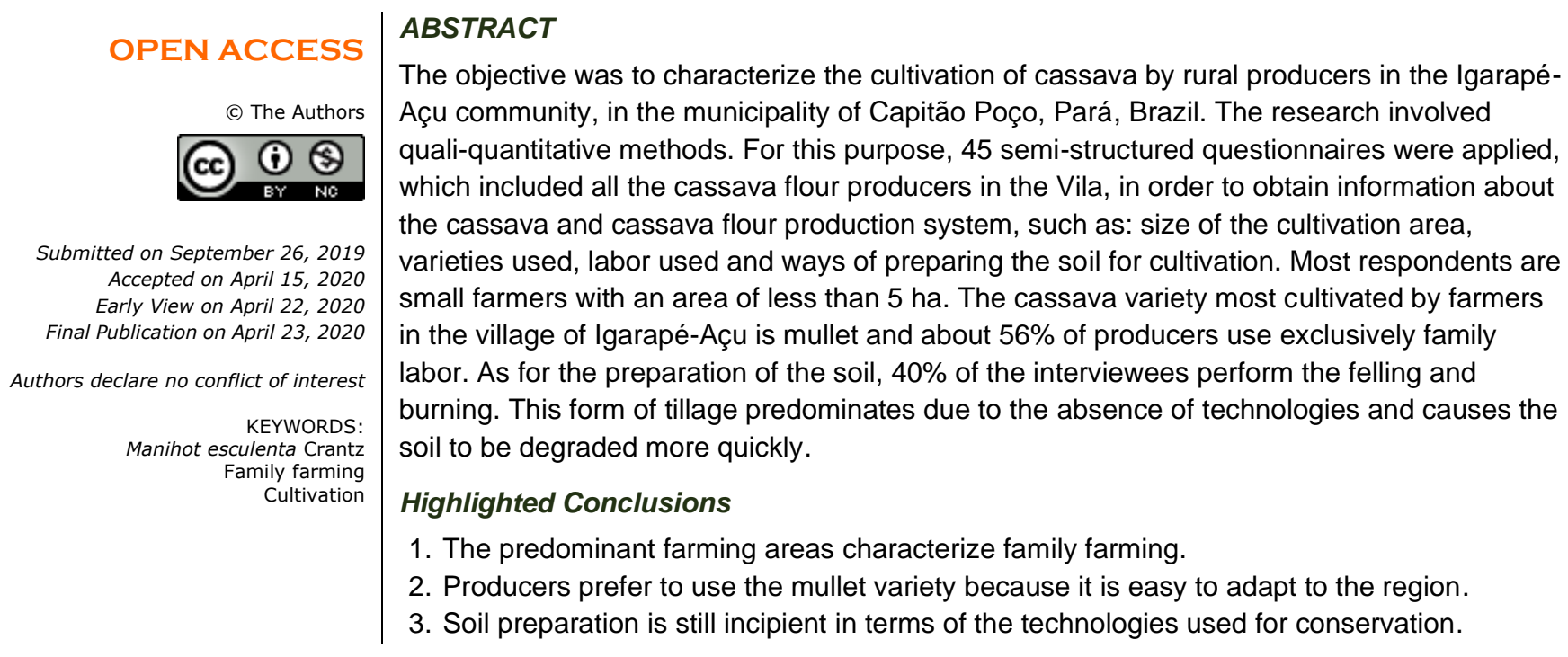

\section{INTRODUCTION}

Cassava (Manihot esculenta Crantz) is a root of Amerindian and Brazilian origin, having spread throughout America, being also taken to Africa and Asia by Portuguese and Spanish colonists (Oliveira 2008). It has several advantages over other agricultural crops, since everything is taken advantage of, from the leaves and stems to the roots. For these and other reasons it has become one of the main sources of food energy for most populations (Buhari 2017).

Cultivated throughout the national territory, cassava is one of the most appreciated foods by Brazilians, especially in the North and Northeast regions, where it is one of the basic products of the population's diet (Portela 2015). The crop has great importance in human and animal food, serving as raw material for industry. One of its most consumed by-products is manioc flour.

In a survey carried out by the United Nations Food and Agriculture Organization (FAO) for the year 2016, the global production of cassava root corresponded to 277.1 million tons. The largest world producer is Nigeria, which in the same year accounted for 57.13 million tons, followed by Thailand and Indonesia. Brazil is the 4th largest producer in the world with 21.08 million tons of cassava root (CONAB 2018). In 2018, national production predicted 19.9 million tons, $3.5 \%$ less than in 2017 , in an estimated harvested area of 1.39 million hectares $(-1.4 \%$ in relation to $2017 \sim 1.40$ million) (Coêlho 2018).

According to the agricultural census of the Brazilian Institute of Geography and Statistics (IBGE 2017), the production of manioc root in Brazil, in the 1st place is the state of Paraná with 1,413,155.365 tons and 2nd place for 1,096,695,515 tons, followed by São Paulo with 646,993,404 tons, respectively. Together, these units of the federation represent almost half of the national production. 
Family farming produces most of the food that supplies the Brazilian table. About $70 \%$ of these foods are produced on small family farms, guaranteeing food sovereignty in the country (Gaboardi Júnior 2013), being one of the main sources of job occupation in rural Brazil.

Mandioculture is especially important due to the $76 \%$ share of family farming in national production (Souza et al., 2012). It is important to stress the estimate by Alves et al. (2019), that the activities related to the cultivation of cassava and its derivatives generate almost one million direct jobs in the country, being 450.000 direct and 500.000 indirect. The Gross Production Value (VBP) of cassava-related agriculture was R $\$ 12.9$ billion in 2017, with a projection of $\mathrm{R} \$ 10.6$ billion for 2018 , according to the Ministry of Agriculture, Livestock and Supply (Brasil 2019).

Cassava production in the Igarapé-Açu community is part of the community's history and carries with it its cultural identity. The production of this is also one of the main subsistence activities of the population of the community, where the majority is provided by family farming, which helps in obtaining income, local supply, among others, in addition to contributing to the municipality's economy. Thus, it is of great importance to gather information about the cassava production chain, since it is a culture that brings benefits to family farmers, not only from the community under study, but also from a large Brazilian population.

Thus, the objective was to characterize the cassava production system in the Igarapé-Açu community, in the municipality of Capitão Poço / PA.

\section{MATERIAL AND METHODS}

The research was carried out in Vila de Igarapé-Açu, belonging to the municipality of Capitão Poço, $25 \mathrm{~km}$ away from the city center (Figure 1). According to the Municipal Health Secretariat, the village has 412 families and is closer $(8 \mathrm{~km})$ to the municipality of Ourém, which belonged for many years. After the creation of the municipality of Capitão Poço, in December 1961, it became part of the boundaries of this municipality.

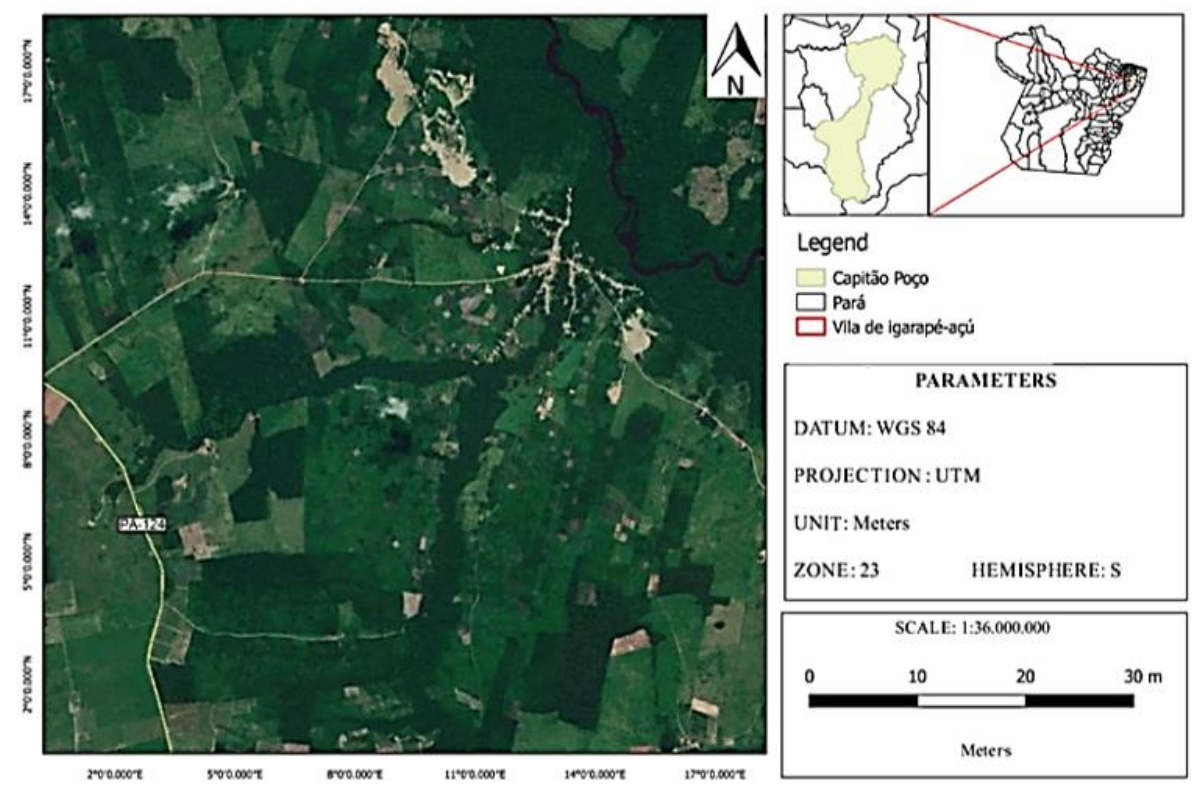

Figure 1. Geographic location of the Igarapé-Açu community, in the municipality of Capitão Poço / PA - Brazil.

Source: Souza et al. (2020)

The research involved quali-quantitative methods. For this purpose, 45 semi-structured questionnaires were applied, which included all the cassava flour producers in the Vila, in order to obtain information about the cassava and cassava flour production system, such as: size of the cultivation area, varieties used, labor used and forms of land use for cultivation.

The data obtained were analyzed and interpreted with the aid of electronic spreadsheets, using Microsoft Excel $2010 \circledast$ software.

\section{RESULTS AND DISCUSSION}

Figure 2 shows the size of the cultivation area used by the cassava producers in Vila de Igarapé-Açu. For better characterization, intervals were created between the sizes of the area used for the production of cassava roots. 
About $42 \%$ of the producers use areas between the range of 0 to 0.9 ha, $40 \%$ use from 1 to 2.9 ha, $13 \%$ use from 3 to 5.9 ha and $4 \%$ use over 6 ha. With this, it is clear that what really prevails in the community is family farming, since most producers have small properties according to Law No. 8,629 / 93, in art. 4th, II. This is because the fiscal module of the municipality of Capitão Poço corresponds to 55 ha (INCRA 2013).

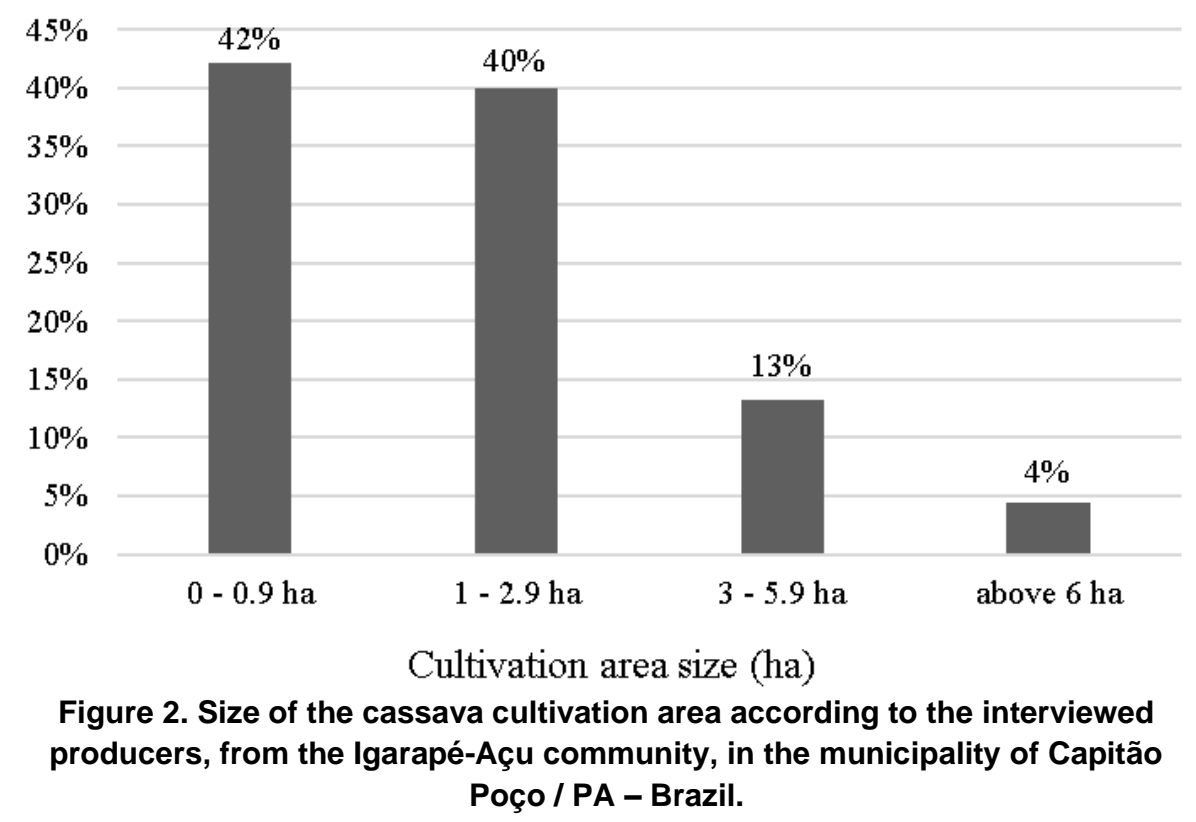

Such observed variations are directly related to the purchasing power of farmers present in the community. This is one of the factors of great limitation for activities aimed at production in family farming (Paula et al. 2014).

The total area of the production units covered by the survey was $62.26 \mathrm{ha}$, which corresponds to an average of 1.38 ha per farmer. In the group of farmers interviewed, the size of the cultivation area varied between a minimum of 0.3 ha and a maximum of 25 ha. Forty-four (44) of the respondents are small farmers who have their areas between 0.3 to 5 ha and only one claimed to have 1 plot ( $25 \mathrm{ha}$ ) of cassava planting. Such values are similar to those of Mendes et al. (2016) in which they verified that the average area of cassava production varied between 0.30 to 3 ha, with water flour being the main by-product benefited by these farmers.

The cassava variety most cultivated by farmers in the village of Igarapé-Açu is tainha (Figure 3). About $60 \%$ of the producers claim to use only this variety as a raw material for the production of cassava flour, $24 \%$ use the tainha variety as main and others as cearense, jurará, gigante, rodinho and tashi, $7 \%$ prefer the tainha and the pecuí, $4 \%$ uses the tainha variety and yellow pecuí, $2 \%$ uses the tainha and bahiana varieties, and only $2 \%$ claims to use only the mirim variety.

Most farmers claim to use the mullet variety, claiming that it is a variety that presents good adaptation to the region, brings good yield for the production of cassava flour, in addition to being resistant to diseases present in the crop.

Cassava production in Vila de Igarapé-Açu is predominantly familiar, not only due to the characterization of the size of the cultivation areas, but also due to the labor employed for the various tasks throughout the production system. Figure 4 shows that about $56 \%$ of producers use exclusively family labor, $27 \%$ say they use family and contracted labor when necessary and only $18 \%$ use only contracted labor. Thus, the predominance of family labor is a characteristic that the cultivation of cassava roots is relevant to the community and is a traditional activity, passed down from generation to generation, since many children are included in the activities.

For Santos (2008), younger farmers and larger families have the highest production of flour. However, the use of female and child labor, whose remuneration is lower, and the payment for services with a product - cassava flour - have been the solution to the low returns of the activity.

In addition, the characterization of labor is directly related to the size of the area for the cultivation of cassava. As seen in Figure 2, most producers cultivate in areas from 0 to 0.9 ha, that is, the size of the area is small, which does not require a large amount of labor to hire more people, in addition to family members, such as children, wife and even other levels of kinship.

Regarding the soil preparation for the cultivation of cassava (Figure 5), it was found that about $40 \%$ of the interviewees cut and burn, $33 \%$ use mechanization with the plow, $14 \%$ use only the plow, $9 \%$ use the plow and 
harrow, and $4 \%$ say they only mow. In addition, it was observed during the survey that producers, in general, do not use inputs for soil correction and disease prevention. Only one claimed to use fertilizer to prepare the planting area.

Despite the prohibitions imposed by Brazilian environmental legislation, such as the use of fire and clearing of primary native forest, there is still a tradition of clearing and burning with the constant opening of new areas, since without technology the soils suffer degradation quickly (Silva 2017). In this system, farmers graze the area, called a drill, and subsequently carry out the clearing, burning of the vegetation and compelling it to, afterwards, carry out the planting (Santos and Santana 2012).

Matos and Cardoso (2002) affirm that plowing, when recommended, in soils with an impediment layer, should reach a maximum of $30 \mathrm{~cm}$ in depth followed by two harrows in a crossed direction, leaving the soil well broken up to be furrowed and planted. With the use of mechanization since the preparation of the soil, with the application of fertilizers and correctives, the productivity of cassava is increased by $50 \%$ compared to the Pará average, bypassing the shortage of labor (Modesto Júnior and Alves 2016).

In conclusion, most respondents are small farmers with an area of less than 5 ha. The most used variety in the Vila is the mullet, as it is the most adapted to the region. Most of the labor force is familiar, as they are small areas and do not require hiring. In addition, soil preparation is used for cultivation in the form of cutting and burning, as the absence of technologies causes the soil to be degraded more quickly.

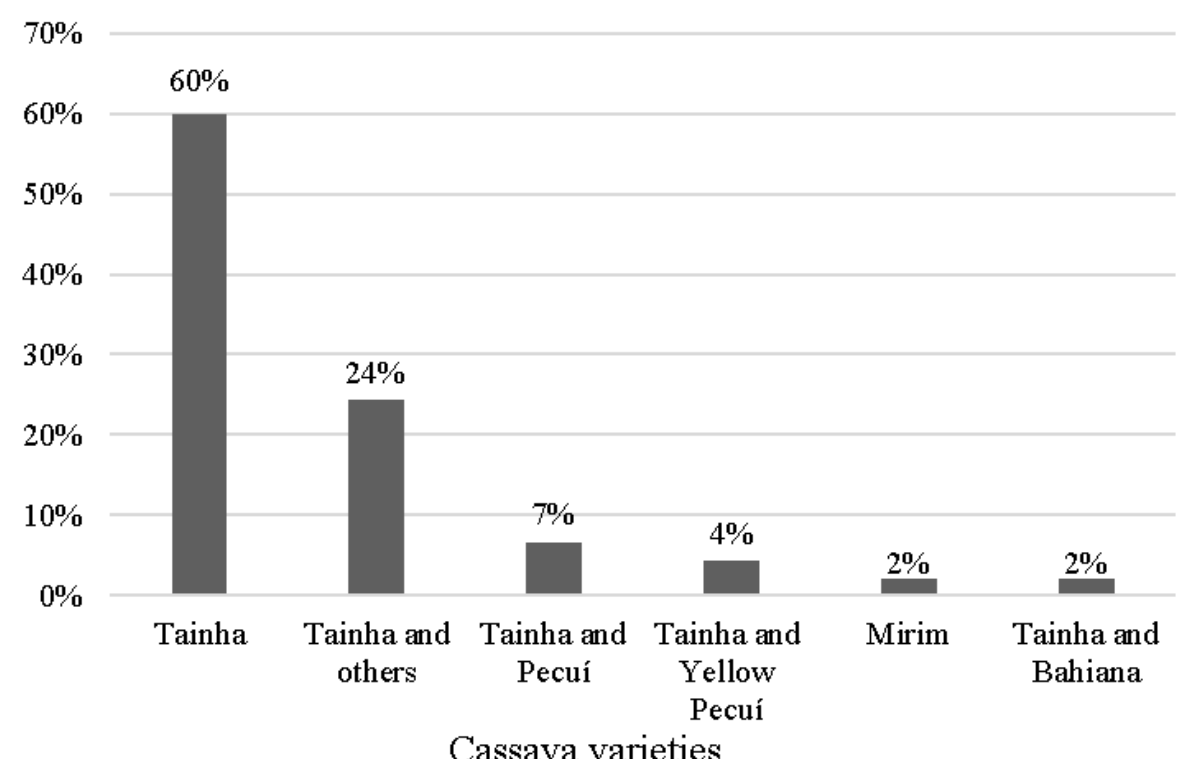

Figure 3. Cassava varieties used by farmers in the Igarapé-Açu community, in the municipality of Capitão Poço / PA - Brazil.

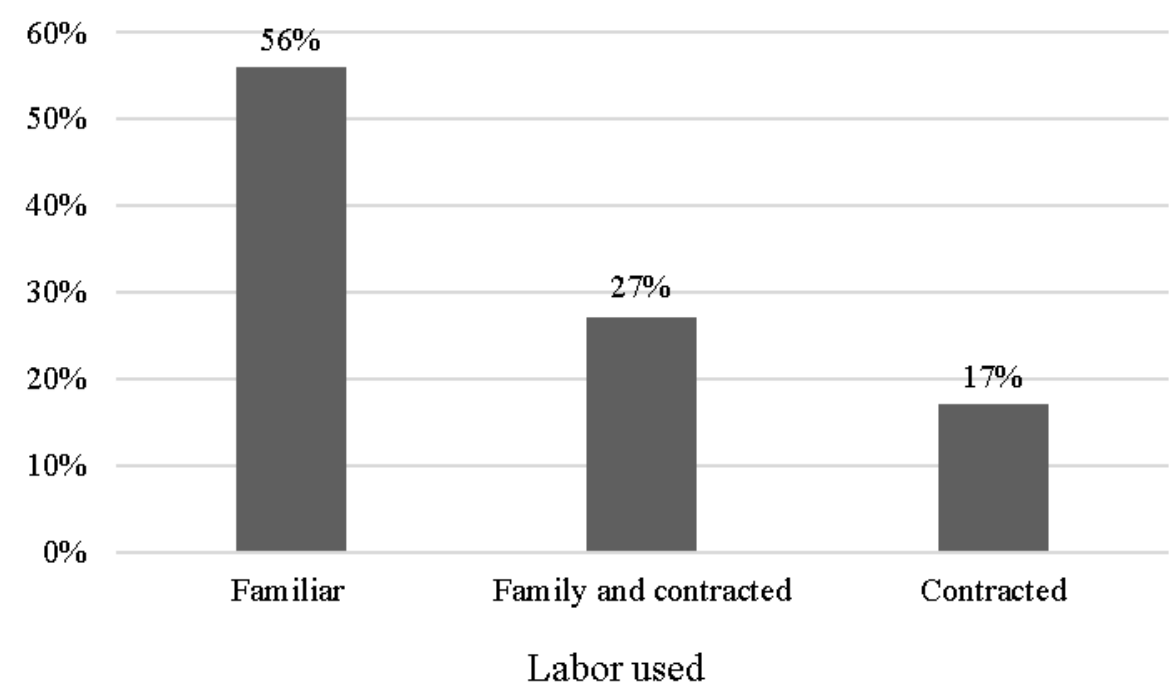

Figure 4. Type of labor used in cassava production in the Igarapé-Açu community, in the municipality of Capitão Poço / PA - Brazil. 


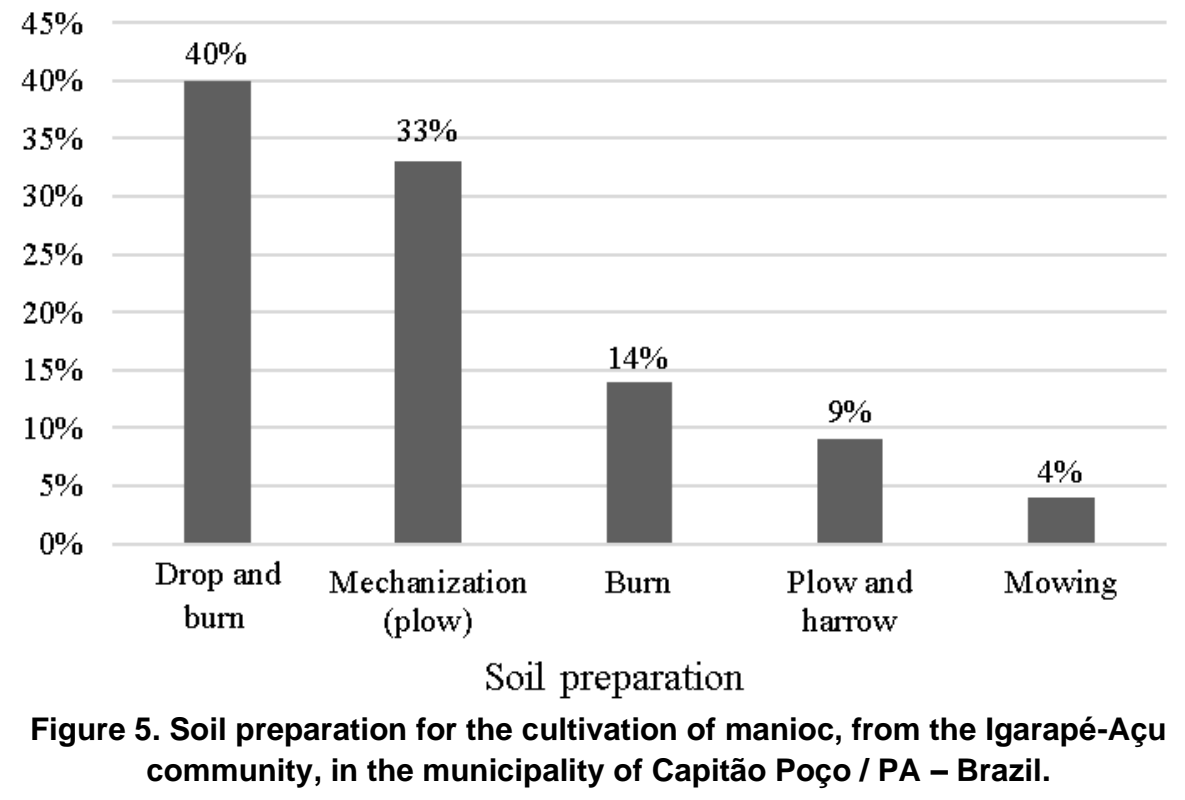

\section{Acknowledgements}

To all the authors involved in the construction of this study, for their commitment and patience in the referred work and, in particular, to the small cassava producers in the Igarapé-Açu community, for having shared the reality lived in the field and passed on all the knowledge and information that were essential for the construction of research.

\section{References}

Alves RNB et al. 2019. Potencialidades da cultura da mandioca para a agricultura familiar do Pará. Available at: https://www.infoteca. cnptia.embrapa.br/bitstream/doc/882846/1/PotencialidadesCulturaMandioca.pdf. Accessed on: Sept. 24, 2019.

Brasil. 2019. Ministério da Agricultura, Pecuária e Abastecimento (MAPA). Valor Bruto da Produção Agrícola (VBP). Available at: http://www.agricultura.gov.br/assuntos/ politica-agricola/valor-bruto-da-producao-agropecuariavbp. Accessed on: Sept. 24, 2019.

Buhari AK. 2017. Profitability of cassava (Manihot esculenta) production in Kebbi state. Ambit Journal of Agricultural Research 2:85-93.

Coêlho JD. 2018. Produção de mandioca: raiz, farinha e fécula. Caderno Setorial ETENE. Ano 03, №44, set. 2018. Banco Nordeste. FortalezaCE. Available at: https://www.bnb.gov.br/documents/80223/4049480/44_Mandioca.pdf/08b8f0c3-b88b-4d40-d5ec-4e2620bdcdde. Accessed on: Feb. 17, 2019.

CONAB. 2018. Companhia Nacional de Abastecimento (CONAB). Análise Mensal: mandioca janeiro/2018. Available at: https://www.conab.gov.br/info-agro/analises-do-mercado-agropecuario-e-extrativista/analises-do-mercado/historico-mensal-demandioca/item/download/15104_87ab84e372faa534fa097d39adcb71c5. Accessed on: Apr. 22, 2020.

Gaboardi Junior A.2013. A importância da produção na agricultura familiar para a segurança alimentar. Available at: http://www.jornadaquestaoagraria.ufpr.br/trabalhos /uploads/trabalho2ujornada.pdf._Accessed on: May 17, 2019.

IBGE. 2017. Instituto Brasileiro de Geografia e Estatística (IBGE). Sistema IBGE de recuperação automática - SIDRA. Disponível em: https://sidra.ibge.gov.br/home/ipca/brasil. Accessed on: Apr. 22, 2020.

INCRA. 2013. Instituto Nacional de Colonização e Reforma Agrária (INCRA). SISTEMA NACIONAL DE CADASTRO RURAL: Índices básicos de 2013. 149p.

Matos PLP, Cardoso EMR. 2003. Cultivo da Mandioca para o Estado do Pará. Embrapa Mandioca e Fruticultura. Sistemas de Produção, 13.

Mendes VQ et al. 2016. Avaliação da cadeia produtiva da mandioca para farinha de mesa na Vila de Igarapé-Açu, Capitão Poço, Pará. Cadernos de Agroecologia 10, $5 p$.

Modesto Júnior MS, Alves RNB. 2016. Cultivo da Mandioca: Aspectos econômicos, melhoramento genético, sistema de cultivo, manejo de pragas e doenças e agroindústria. Available at: https://www.embrapa.br/busca-de-publicacoes/-/publicacao/1056630/cultura-da-mandiocaaspectos-socioeconomicos-melhoramento-genetico-sistemas-de-cultivo-manejo-de-pragas-e-doencas-e-agroindustria. Accessed on: Sept. 24, 2019.

Oliveira LL. 2008. Perfil higiênico-sanitário das unidades de processamento da farinha de mandioca (Manihot esculenta Crantz) na região sudoeste da Bahia. Itapetinga (BA): Dissertação (Mestrado), Universidade Estadual do Sudoeste da Bahia.

Paula MM et al. 2014. Mercados institucionais na agricultura familiar: dificuldades e desafios. Revista de Política Agrícola 23:33-43.

Portella AL. 2015. Caracterização do processo produtivo, aspectos da qualidade da farinha de mandioca e percepção dos agentes da cadeia na região central do Estado de Roraima. Tese (Mestrado profissional em Defesa Sanitária Vegetal) - Universidade Federal de Viçosa.

Santos JC. 2008. Sustentabilidade socioeconômica e ambiental de sistemas de uso da terra da agricultura familiar do Estado do Acre. Tese (Doutorado) - Programa de Pós-graduação em Economia Aplicada, Universidade Federal de Viçosa, Viçosa, MG.

Santos MAS, Santana AC. 2012. Caracterização socioeconômica da produção e comercialização de farinha de mandioca no município de Portel, arquipélago do Marajó, Estado do Pará. Revista Verde 7:73-86.

Silva FAC et al. 2017. Contexto Econômico e Social da Produção de Farinha de Mandioca na Regional do Juruá, Acre. In: Souza JML et al. (Eds.). Indicação geográfica da farinha de mandioca de Cruzeiro do Sul, Acre. Rio Branco, AC: Embrapa Acre. pp.81-95.

Souza E. et al. 2012. A cadeia produtiva da mandiocultura no vale do Jequitinhonha (MG): Uma análise dos aspectos sócio produtivos, culturais e da geração de renda para a Agricultura familiar. Revista: ISEGORIA, Ação Coletiva em Revista 1:73-85.

Souza SKA et al. 2020. Socioeconomic profile of cassava flour producers: a study on Vila de Igarapé-Açu, Capitão Poço, Pará, Brazil. Communications in Plant Sciences 10:27-31. 